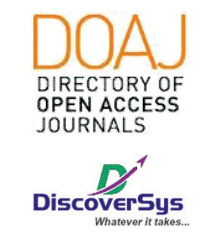

Published by DiscoverSys

\section{Keloid aurikularis dekstra yang diterapi kombinasi eksisi intralesi dan injeksi kortikosteroid dengan anestesi tumesen: Sebuah laporan kasus}

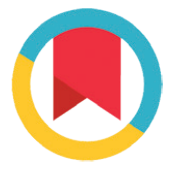

CrossMark

Ida Ayu Intan Pratiwi, ${ }^{1 *}$ Made Wardhana²

\section{ASBTARCT}

Introduction: Keloid is a skin lesion due to overproduction of collagen and fibroblasts. Has predilection on high tension skin and there are various modalities in handling them. The purpose of this case report is to provide a perspective of auricular keloids treated by a combination of intralesional excision and corticosteroid injection with tumescent anaesthesia.

Case: A 28-year-old woman who has a history of small nodules on the right ear that is getting bigger and bigger. Dermatological status shows the right auricular helix region obtained nodules brown, solitary, oval shape, size $5 \times 7 \mathrm{~cm}$, firm boundaries, regular edges, smooth surface and shiny. In palpation hard and fixed fixation is found. Patients were treated with a combination of intralesional excision and corticosteroid injection with tumesent anaesthesia. Corticosteroid injection used was triamcinolone acetonide as much as 0.4 cc intra-lesion on the $3 \mathrm{rd}$ day. Control on the 7th day the patient was in good condition and did not appear to have any complications with the condition of the postsurgical wound being treated.

Conclusion: Management of auricular keloids by intralesional excision and corticosteroid injection after three days post-surgery provides the satisfactory clinical outcome of keloids.

Keywords: keloids, surgery, therapy, corticosteroids, injection.

Cite This Article: Pratiwi, I.A.I., Wardhana, M. 2020. Keloid aurikularis dekstra yang diterapi kombinasi eksisi intralesi dan injeksi kortikosteroid dengan anestesi tumesen: Sebuah laporan kasus. Intisari Sains Medis 11(2): 497-503. D0I: 10.15562/ism.v11i2.640

\title{
ABSTRAK
}

Pendahuluan: Keloid merupakan suatu lesi kulit oleh karena produksi berlebihan dari kolagen dan fibroblast. Memiliki predileksi pada kuit yang memiliki tegangan tinggi dan terdapat berbagai modalitas dalam penanganannya. Tujuan dari laporan kasus ini adalah memberikan perspektif keloid aurikularis yang diterapi kombinasi eksisi intralesi dan injeksi kortikosteroid dengan anestesi tumesen.

${ }^{1}$ Program Pendidikan Dokter Speasialis-1 Kulit dan Kelamin, Fakultas Kedokteran, Universitas Udayana-RSUP Sanglah Denpasar, Bali-Indonesia.

${ }^{2}$ Departemen/KSM IImu Penyakit Kulit dan Kelamin, Fakultas Kedokteran, Universitas UdayanaRSUP Sanglah Denpasar, BaliIndonesia.

${ }^{*}$ Correspondence to: Ida Ayu Intan Pratiwi, Program Pendidikan Dokter Speasialis-1 Kulit dan Kelamin, Fakultas Kedokteran, Universitas Udayana-RSUP Sanglah Denpasar, Bali-Indonesia. ia.intanpratiwi@gmail.com

Diterima: 09-10-2019

Disetujui: $10-07-2020$

Diterbitkan: 01-08-2020
Kasus: Seorang perempuan berusia 28 tahun yang memiliki riwayat bintil kecil pada telinga kanan yang makin lama makin membesar. Status dermatologis menunjukkan regio helix aurikularis dekstra didapatkan nodul berwarna kecokelatan, soliter, bentuk oval,
Kata kunci: keloid, bedah, terapi, kortikosteroid, injeksi.

\section{PENDAHULUAN}

Keloid merupakan lesi yang menebal, meninggi serta meluas melebihi batas luka yang ditandai dengan adanya produksi serat kolagen yang berlebihan serta hiperplasia fibroblas. Lesi keloid timbul setelah terjadi trauma, inflamasi, pembedahan atau luka bakar pada individu dengan predisposisi. Keloid jarang mengalami regresi sehingga ukuran $5 \times 7 \mathrm{~cm}$, batas tegas, tepi regular, permukaan halus dan mengkilat. Pada palpasi didapatkan kosistensi keras dan terfiksir. Pasien di berikan tatalaksana kombinasi eksisi intralesi dan injeksi kortikosteroid dengan anestesi tumesen. Injeksi kortikosteroid yang digunakan adalah triamcinolone acetonid sebanyak 0,4 cc intra lesi pada hari ke-3. Kontrol pada hari ke-7 pasien dengan kondisi baik dan tidak tampak suatu komplikasi apapun dengan kondisi luka paska bedah yang terawatt.

Simpulan: Penanganan keloid aurikularis dengan teknik eksisi intralesi dan injeksi kortikosteroid tiga hari paska bedah memberikan luaran klinis keloid yang memuaskan.

Cite Pasal Ini: Pratiwi, I.A.I., Wardhana, M. 2020. Keloid aurikularis dekstra yang diterapi kombinasi eksisi intralesi dan injeksi kortikosteroid dengan anestesi tumesen: Sebuah laporan kasus. Intisari Sains Medis 11(2): 497-503. D0I: 10.15562/ism.v11i2.640

seringkali memberikan dapat sosial dan psikologis pada individu dengan keloid. ${ }^{1,2}$

Keloid tampak secara klinis berupa nodul, berwarna hiperpigmentasi atau merah muda sampai kecoklatan dengan batas tegas. Permukaan biasanya halus dan mengkilat dengan tepi rata, namun dapat ireguler. ${ }^{1}$ Predileksi keloid pada 
tempat-tempat tegangan kulit yang tinggi seperti pada sternum, bahu, mandibular dan lengan. Pada daerah wajah salah satu bagian yang sering berkembang menjadi keloid adalah telinga. ${ }^{3}$ Bagian telinga luar merupakan area anatomi yang mudah mengalami kelainan proses penyembuhan luka sehingga mengakibatkan terjadinya keloid. Kelainan ini lebih sering mengenai ras kulit hitam dan lebih banyak terjadi pada remaja dan dewasa muda antara usia 10 sampai 30 tahun. $^{4}$

Banyak modalitas terapi yang tersedia untuk keloid, salah satunya adalah injeksi steroid intralesi. Modalitas terapi ini biasanya digunakan sebagai terapi lini pertama maupun terapi preventif yang biasanya dikombinasikan dengan tindakan bedah. Beberapa terapi lainnya yang disarankan selain injeksi steroid intralesi dan pembedahan eksisi adalah radioterapi, cryotherapy, terapi kompresi, laser dengan carbon dioxide $\left(\mathrm{CO}_{2}\right)$ atauneodymium:yttrium-aluminium-garnet (Nd:Yag), terapi antimitosis topikal seperti 5-fluorouracil (5-FU), bleomycin, verapamil, serta imiquimod., 4

Tindakan operasi yang dilakukan didaerah telinga umumnya rentan terhadap perdarahan. Ini disebabkan oleh kompleksitas pembuluh darah yang ada di area tersebut. Oleh karenanya, diperlukan metode anestesi yang mampu membantu operator untuk menekan perdarahan di daerah tersebut. Salah satu jenis yang teknik anestesi lokal sering digunakan pada bedah kulit adalah teknik tumesen (tumescent) dimana teknik ini memiliki efek infiltrasi langsung tanpa memerlukan sedasi. Teknik tumesen memiliki berbagai keuntungan, seperti mengurangi perdarahan, melindungi oragan yang berada di bawah kulit, dan juga dapat mengurangi kemungkinan untuk infeksi. ${ }^{6,20}$

Berikut dilaporkan kasus keloid aurikularis dekstra yang diterapi kombinasi eksisi intralesi dan injeksi kortikosteroid dengan anestesi tumesen. Kasus ini dilaporkan untuk menambah pengetahuan dan pemahaman mengenai penatalaksanaan keloid.

\section{LAPORAN KASUS}

Seorang perempuan berusia 28 tahun, suku Bali, warga negara Indonesia, datang ke praktek dokter spesialis kulit dan kelamin pada tanggal 25 September 2018 dengan keluhan utama tumbuh benjolan sewarna kulit pada cuping bagian atas telinga kanan.

Berdasarkan anamnesis, benjolan ini muncul sejak 5 tahun yang lalu setelah sebelumnya pasien melakukan pengangkatan. Awalnya berupa bintil kecil yang terkadang terasa gatal dan terkadang digaruk. Bintil tersebut semakin lama semakin membesar, membentuk benjolan di melebihi luka bekas operasi. Pasien sering merasa malu akibat ukuran benjolan yang bertambah besar. Hal ini membuat pasien ingin menghilangkan benjolan tersebut. Riwayat pengobatan, pernah melakukan pengobatan pada benjolan tersebut yaitu dengan suntikan pada telinga setiap bulan, terakhir 4 bulan yang lalu namun tidak ada perbaikan dan operasi sebanyak tiga kali di rumah sakit Singaraja. Riwayat penyakit dahulu, pertama kali keluhan muncul saat pasien berusia 2 tahun dimana pada bagian tersebut tidak sengaja tersiram air panas.

Pemeriksaan dermatologi pada lokasi regio helix aurikularis dekstra didapatkan nodul berwarna kecokelatan, soliter, bentuk oval, ukuran $5 \times 7 \mathrm{~cm}$, batas tegas, tepi regular, permukaan halus dan mengkilat. Pada palpasi didapatkan kosistensi keras dan terfiksir (Gambar 1).

Berdasarkan anamnesis dan pemeriksaan fisik pasien didiagnosis dengan keloid aurikularis dekstra. Penatalaksanaan pada pasien adalah tindakan bedah eksisi. Pasien dibaringkan di atas meja operasi dalam posisi telentang dengan kepala miring ke sebelah kiri. Operator mencuci tangan dan menggenakan sarung tangan steril. Lapangan operasi didesinfeksi menggunakan povidin iodin dan larutan salin kemudian dipersempit dengan doek lubang steril. Sebelum operasi

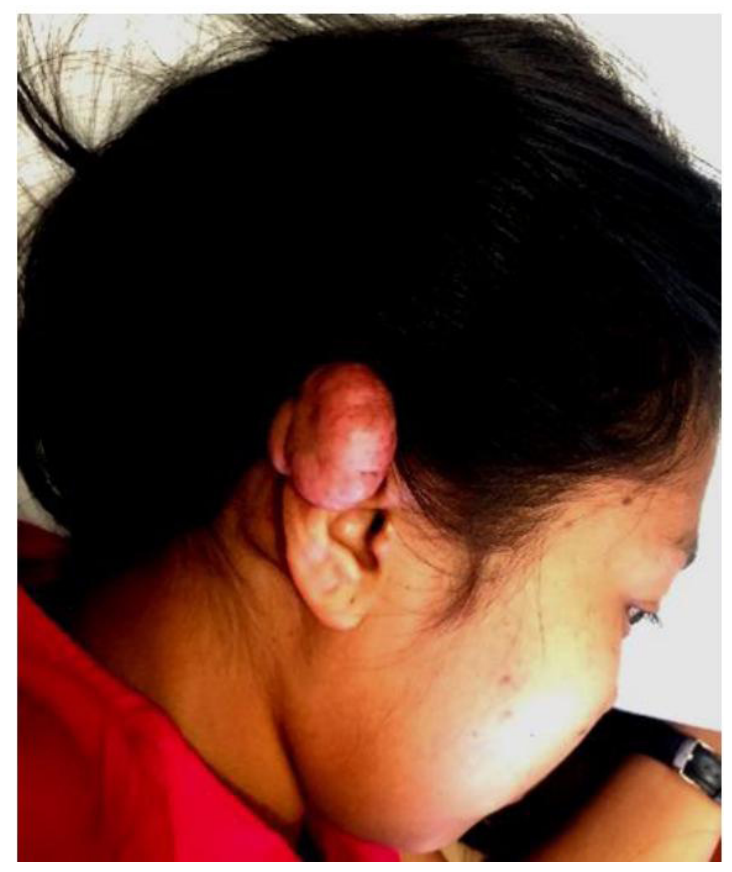

Gambar 1 Regio helix aurikularis dekstra didapatkan nodul kecokelatan, soliter, bentuk oval, ukuran $4 \times 6 \mathrm{~cm}$, batas tegas, tepi regular, permukaan halus dan mengkilat. Pada palpasi didapatkan kosistensi keras dan terfiksir 


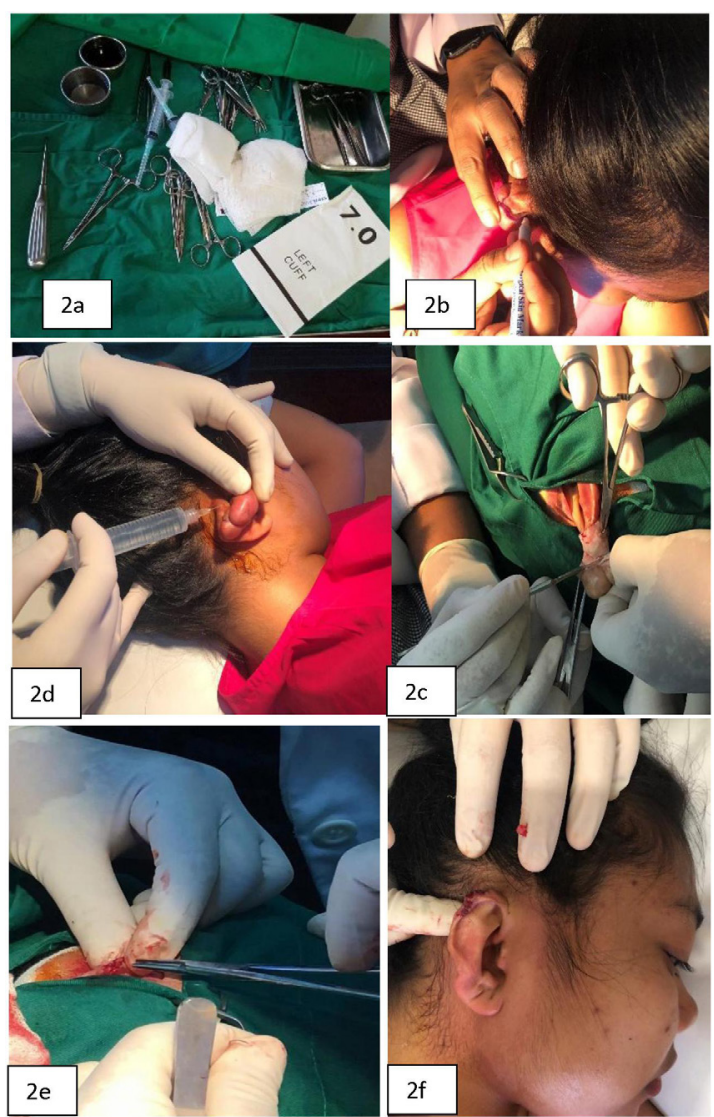

Gambar 2 (a) persiapan alat; (b) marker; (c) teknik tumesen local; (d) eksisi intralesi dan perdarahan

Minimal;(e)dilakukanjahitan; (f) luka dibersihkan povidon iodine $+\mathrm{Nacl}$ 0,9\%, kemudian dikeringkan
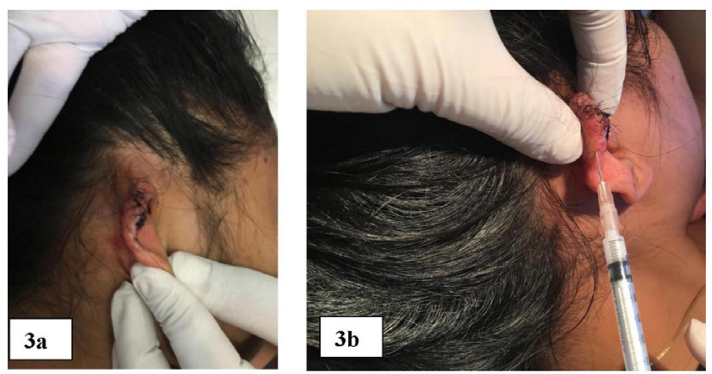

Gambar 3 (a) Luka jahitan pada hari ke-3 pasca operasi; (b) injeksi triamcinolone acetonide pertama pasca eksisi

dimulai, dilakukan persiapan alat-alat yang akan digunakan (Gambar 2a). Pada daerah lesi dibuat pemetaan (marker) (Gambar 2b), lalu lapangan operasi didesinfeksi dengan menggunakan larutan povidon iodine $10 \%$ dan dipersempit dengan melakukan penutupan menggunakan doek steril. Selanjutnya dilakukan injeksi anestesi dengan teknik tumesen yaitu menggunakan pehacain yang kemudian ditambahkan nacl 0,9\% hingga pada daerah disekitar lesi (Gambar 2c). Pada lesi

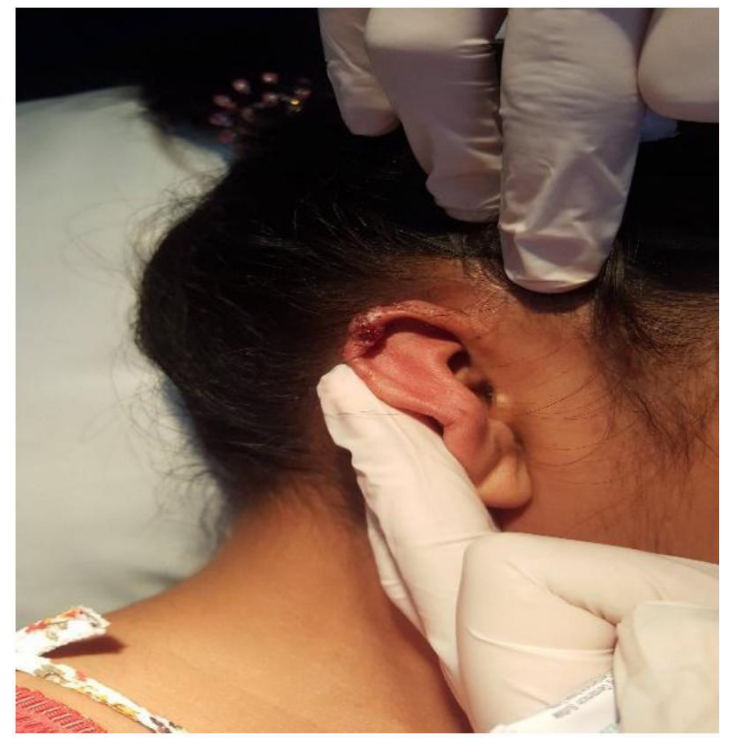

Gambar 4 Luka jahitan pada dahi pasien hari ke-12 pasca operasi

keloid dilakukan eksisi sesuai dengan marker yang dibuat mengelilingi lesi Kemudian lesi diangkat dan dipisahkan dari jaringan dibawahnya dan dilakukan penekanan dengan kassa steril untuk menghentikan pendarahan (Gambar 2d). Kulit dijahit dengan teknik simple interrupted sutures menggunakan benang nilon 5.0 (Gambar 2e). Luka dibersihkan dengan povidon iodine 10\% dan $\mathrm{NaCl}$ 0,9\% kemudian dikeringkan (Gambar 2f). Setelah tindakan operasi selesai, dioleskan salep gentamisin $0,3 \%$ pada daerah penjahitan dan luka operasi ditutup dengan hipafiks.

Terapi paska operasi adalah pemberian antibiotik sefadroxil $500 \mathrm{mg}$ setiap 12 jam per oral selama 7 hari, asam mefenamat 500 mg setiap 8 jam per oral bila nyeri, dan asam tranexamat $500 \mathrm{mg}$ tiap 8 jam dan pada pasien diberikan edukasi untuk menjaga luka jahitan agar tetap bersih dan kering. Pasien direncanakan kontrol 3 hari pasca operasi untuk rawat luka. Pasien diberikan instruksi untuk menghindari kontak dengan air pada area yang dilakukan tindakan tersebut selama 3 hari

\section{Pengamatan lanjutan ke-1: hari ke-3 paska tindakan operasi}

Pasien datang kontrol untuk dilakukan pengangkatan jahitan. Pada anamnesis didapatkan pasien mengeluh nyeri, gatal tidak dirasakan, dan tidak ada perdarahan pada luka. Status dermatologis, pada regio helix aurikularis dekstra, tampak bekas luka jahitan berbentuk linear dengan panjang $10 \mathrm{~cm}$ dan terdapat 8 jahitan yang tertutup dengan baik, tidak ada edema, perdarahan, nekrosis, hematoma maupun tanda-tanda infeksi sekunder (Gambar 3a). Penatalaksanaan yang diberikan adalah rawat luka, luka dibersihkan dengan larutan 
Nacl 0,9\%, penyuntikan triamcinolone acetonide sebanyak $0,4 \mathrm{cc}$, setelah itu dioleskan gentamisin $0,3 \%$ krim topikal ditutup dengan kassa steril untuk sementara. Kontrol dilakukan selanjutnya untuk mengangkat jahitan yaitu hari ke-7 (Gambar 3b).

\section{Pengamatan lanjutan ke-2: hari ke-7 paska tindakan operasi}

Pasien datang kontrol untuk dilakukan pengangkatan jahitan. Pada anamnesis didapatkan tidak ada keluhan nyeri ataupun gatal, dan tidak ada perdarahan pada luka. Status dermatologis, pada regio helix aurikularis dekstra, tampak bekas luka jahitan berbentuk linear dengan panjang $10 \mathrm{~cm}$ dan terdapat 8 jahitan yang tertutup dengan baik, tidak ada edema, perdarahan, nekrosis, hematoma maupun tanda-tanda infeksi sekunder (Gambar 4). Penatalaksanaan yang diberikan adalah rawat luka, luka dibersihkan dengan larutan Nacl 0,9\%, dan dilakukan pengangkatan jahitan, setelah itu dioleskan gentamisin 0,3\% krim topikal ditutup dengan kassa steril. Kontrol dilakukan selanjutnya 2 minggu lagi untuk injeksi steroid.

\section{PEMBAHASAN}

Keloid merupakan pertumbuhan berlebih dari jaringan ikat padat yang biasanya terjadi setelah penyembuhan luka pada kulit. ${ }^{7-10}$ Deskripsi keloid pertama kali digunakan di Mesir pada 1700 sebelum masehi. Pada tahun 1806, Alibert menggunakan istilah cheloid, diambil dari bahasa Yunani chele atau "crab claw" untuk menggambarkan pertumbuhan jaringan kearah lateral dari area kulit yang tidak terlibat. ${ }^{9,11}$

Lesi keloid biasanya timbul setelah trauma kulit lokal (misalnya laserasi, tato, luka bakar, injeksi, pemakaian anting-anting, vaksinasi atau pembedahan), gangguan peradangan kulit (seperti akne, gigitan serangga atau infeksi). Pengaruh hormon juga ikut berperan terhadap terjadinya pertumbuhan keloid atau keloid melebar selama hamil.,11 Keloid dapat muncul dalam beberapa minggu, bulan atau tahun setelah trauma pada area dengan tegangan kulit yang tinggi. ${ }^{9,5}$ Diagnosis keloid biasanya mudah jika terdapat riwayat trauma atau peradangan kulit. Pada kasus pasien memiliki riwayat trauma setelah terkena air panas ketika masih balita. Keloid pada pasien muncul dalam waktu beberapa tahun dari setelah terjadinya trauma.

Pembentukan skar pada dermis merupakan hasil dari proses penyembuhan luka yang kompleks yang terdiri dari fase koagulasi, inflamasi, proliferasi dan remodeling. Setelah terjadi luka, terjadi degranulasi platelet dan aktivasi komplemen serta pembentukan fibrin klot. Degranulasi bertanggung jawab untuk pelepasan dan aktivasi dari sitokin dan growth factor, sebagai agen kemotaktik untuk menarik makrofag, netrofil, fibroblas dan sel lain. Sintesis fibroblas dari maktriks ekstraseluler menyusun kerangka penutupan luka dan vaskularisasi. Saat luka tertutup, matriks ekstraseluler yang berlebihan didegradasi dan kolagen tipe III imatur diubah menjadi kolagen tipe I matur. ${ }^{5,12}$ Transformasi dari klot luka6ytr menjadi jaringan granulasi diperlukan suatu keseimbangan antara deposisi dan degradasi protein matriks ekstraseluler dan saat ini terganggu, muncul skar yang abnormal. Sel inflamasi melepas faktor fibrogenik seperti TGF- $\beta 1$ dan $\beta 2$, kondisi ini meningkatkan akumulasi matriks ekstraseluler sementara degradasi terganggu. Peningkatan respon Th-2 menyebabkan fibrogenesis, sedangkan Th-1 menurunkan fibrosis jaringan. Keloid dapat tumbuh melebihi batas lesi akibat pemanjangan waktu inflamasi dengan infiltrat sel imun yang meningkatkan aktivitas fibroblas dan menambah deposisi matriks ekstraseluler. ${ }^{11,12}$

Chang-Park membuat suatu modifikasi klasifikasi keloid pada telinga menjadi tipe I yaitu tipe pedunculated, tipe II tipe sessile, tunggal, tipe III tipe sessile, multipel, tipe IV burried, dan tipe V campuran/mixed. ${ }^{13}$ Tujuan Chang-Park membuat kasifikasi ini adalah untuk meningkatkan pemahaman mengenai keloid pada telinga dan mencocokan dengan pendekatan bedah yang tepat. Menurut Park dan kawan-kawan pemilihan metode bedah yang sesuai tergantung kepada penampakan keloid itu sendiri. Klasifikasi yang sesuai yang dapat menggambarkan massa keloid dan mengelompokkan hubungannya dengan struktur kulit yang normal dapat membantu menentukan metode bedah yang sesuai dan meramalkan hasil akhir pada pengamatan jangka panjang. Telinga memiliki struktur 3D yang kompleks dengan jaringan subkutan yang relatif minimal, pendekatan bedah yang sesuai dengan lokasi dimensi keloid amat penting. Pada suatu studi keloid yang berukuran kurang dari 1,5 cm akan dilakukan eksisi komplit. Apabila telah terbentuk massa yang cukup besar hingga membentuk tumor di telinga maka diperlukan metode rekonstruksi untuk mempertahankan bentuk telinga. Namun terkadang eksisi total dapat menstimulasi tambahan sintesis kolagen, dimana hal ini dapat menyebabkan ukuran keloid yang lebih besar daripada sebelumnya. ${ }^{11,13}$ Tipe pada kasus adalah tipe I yaitu pedunculated.

Salah satu modalitas terapi keloid adalah bedah eksisi. Secara umum tujuan utama berbagai prosedur eksisi adalah untuk mengangkat tumor secara keseluruhan. ${ }^{14,17}$ Besarnya batas pembedahan harus berkaitan dengan kemungkinan adanya perluasan tumor subklinis. Eksisi meliputi keseluruhan ketebalan kulit sampai lemak subkutan 
dan luka ditutup dengan jahitan primer. Elemen yang harus diperhatikan untuk keberhasilan dalam tindakan pembedahan eksisional secara umum antara lain penggunaan teknik yang steril, penggunaan anestesi lokal, merencanakan arah eksisi dan memperhatikan garis tegangan kulit, teknik atraumatik dalam melakukan insisi dan undermining, hemostasis dan penjahitan, disertai perawatan luka paska operasi dan mengatasi nyeri. ${ }^{15,16}$ Eksisi yang sering dilakukan untuk penanganan keloid adalah eksisi intralesi. Eksisi ini biasanya dibuat dengan meninggalkan pinggiran tipis keloid pada pembedahan. Hal ini diharapkan dapat menghindari risiko tercetusnya respon inflamasi yang intens pada jaringan yang mengelilinginya, yaitu pada kulit yang rentan terkena keloid. Bagian kulit ini dikatakan memiliki peluang untuk menjadi keloid yang lebih besar daripada sebelumnya. Bedah eksisi dalam penanganan keloid sebetulnya memiki angka rekurensi yang tinggi yaitu sekitar $50-100 \%$. Oleh karena itu jarang sekali digunakan sebagai monoterapi. Pembedahan yang dilakukan bertujuan untuk menghilangkan jaringan parut yang berlebihan sehingga dapat mengembalikan luka kepada bentuk semula.Terbentuknya jaringan parut pasca tindakan pembedahan akan ditekan dengan penggunaan terapi salah satunya dengan injeksi kortikosteroid intralesi. Pada penelitian yang dilakukan oleh Lee dan kawan-kawan, pada suatu seri tindakan eksisi intralesi keloid tanpa terapi ajuvan streoid, didapatkan pertumbuhan skar yang tersisa pasca operasi apabila injeksi dilakukan melewati minggu ke-3 pasca operasi.

Penggunaan injeksi kortikosteroid sebagai terapi ajuvan pasca eksisi keloid telah dilaporkan dengan berbagai variasi dosis, jadwal dan konsentrasi obat. Pada suatu penelitian dikatakan bahwa tingkat rekurensi keloid sekitar 0-87\%, lebih spesifik lagi 0-33\% untuk kejadian keloid pada telinga. ${ }^{8}$ Angka ini dikatakan lebih rendah untuk kejadian keloid dibandingkan daerah lainnya. Penelitian lainnya yang dilakukan oleh Shon dan Press menyatakan bahwa angka rekurensi keloid pada telinga hanya 3\%, dimana injeksi kortikosteroid diberikan dengan dosis $40 \mathrm{mg} / \mathrm{ml}$ yang dimulai 3 minggu pasca eksisi dan diulangi dengan interval 4 minggu. Penelitian yang dilakukan Singleton dan Gross melaporkan bahwa injeksi yang dilakukan segera pasca eksisi pada kemudian diulangi tiap 1 bulan menunjukkan respon terapi yang baik. Pada keseluruhan 21 pasien yang diikuti selama satu tahun, 13 memberikan hasil yang baik dan hanya 2 yang mengalami rekurensi. Sedangkan untuk 33 pasien yang diikuti selama setengah tahun, 24 memperlihatkan hasil yang baik, sedangkan 2 mengalami rekurensi. ${ }^{10,18}$
Mekanisme kerja kortikosteroid sendiri yaitu menghambat sintesa kolagen, sintesa glikosaminoglikan, proses inflamasi pada luka dan proliferasi fibroblast, dimana hal ini menguntungkan terutama pada tahap awal terjadinya keloid. Efek yang dimiliki oleh kortikosteroid dapat dipergunakan untuk menekan kemungkinan rekurensi pasca operasi eksisi. Seperti halnya penelitian-penelitian yang telah dijelaskan diatas, injeksi dapat dilakukan pasca eksisi, segera setelah eksisi, namun dapat pula sebelum eksisi, dimana pada kasus operasi merupakan hal yang tidak dapat dihindarkan. Hal ini menurut Farrow dan Stambaugh adalah suatu rasionalisasi, mengingat sebagian besar pasien keloid adalah pasien yang tidak patuh terhadap pengobatan. Injeksi yang dilakukan sebelum tindakan adalah untuk menanamkan pemahaman bahwa pengobatan ini harus dilanjutkan secara berkesinambungan untuk menekan pertumbuhan keloid. Dosis yang digunakan saat injeksi dilakukan segera setelah eksisi adalah $10 \mathrm{mg} / \mathrm{ml}$. Sedangkan dosis injeksi sebelum dan setelah eksisi berkisar antara10-40 mg/ml. Injeksi yang dilakukan pasca operasi,pada beberapa studi dilakukan minimal 3 kali dengan interval 4 minggu, bahkan bila tidak ada tanda-tanda rekurensi. Hal yang harus diperhatikan pada saat injeksi adalah mencegah adanya ekstravasasi kortikosteroid ke jaringan sekitarnya. Hal ini dapat mengakibatkan atrofi pada jaringan, telangiektasia,hipopigmentasi dan kemungkinan perburukan dari kondisi sebelumnya. ${ }^{11-13,19}$

Total dosis yang dapat diberikan adalah 0,1-1 ml triamsionolon asetonid (TA) $(10-40 \mathrm{mg} / \mathrm{ml})$ tergantung dari ukuran dan aktivitas dari sisa lesi. ${ }^{20}$ Jumlah minimum dosis yang diberikan adalah $1 \mathrm{mg}$ TA untuk $1 \mathrm{~cm}^{2}$ lesi. Suntikan diberikan hingga area paska eksisi tampak pucat, sebagai indikator bahwa steroid telah memenuhi area tersebut. ${ }^{21}$

Pada kasus ini dipilih tindakan eksisi, oleh karena keloid terlalu besar dan keras. Injeksi kortikosteroid intralesi akan memerlukan waktu yang lama dan rasa sakit setiap kali penyuntikan, kulit akan tampak kendur, sehingga secara kosmetik akan terlihat buruk. Terapi ajuvan yang dipilih adalah injeksi kortikosteroid, yang dimulai pada hari ke-3 pasca operasi Teknik penjahitan yang dilakukan pada pasien ini adalah simple interrupted suture. Pada kasus, tidak ditemukan adanya komplikasi jangka pendek, sedangkan komplikasi jangka panjang belum dapat dievaluasi.

Teknik tumesen (tumescent) adalah teknik anestesi yang dikembangkan oleh Klein pada tahun 1975 yang sering digunakan dalam tindakan liposuction atau sedot lemak. Teknik tumesen memungkinkan anestesi lokal regional pada kulit dan jaringan subkutan dengan menyebabkan infiltrasi 
langsung. Teknik tumesen pada proses anastesi lokal untuk wilayah yang luas seperti pada liposuctionakan digunakan formula campuran lidokain 0,05-0,1\% denganepineprin 1:1.000.000 dalam $1000 \mathrm{ml}$ larutan salin (Nacl 0,9\%). Sodium bikarbonat $\left(\mathrm{NaHCO}_{3}\right)$ dapat ditambahkan pada formula Klein dengan tujuan mengurangi nyeri saat infiltrasi dan untuk meningkatan aktivitas antibiotik pada lidokain. ${ }^{20}$ Infiltrasi dimulai perlahan dan secara bertahap dipercepat. Infiltrasi subkutan yang lebih dalam dilakukan terlebih dahulu, kemudian dilanjutkan dengan lapisan atas subkutan. Obat anestesi disuntikkan sampai jaringan lemak membengkak dan mengeras. Dosis tertinggi epinefrin yang dapat digunakan adalah $35-50 \mathrm{mg} / \mathrm{kgBB}$, sedangkan dosis tertinggi lidokain yang masih aman adalah $55 \mathrm{mg} / \mathrm{kgBB}$, dan dosis toksik lidokain adalah $>57 \mathrm{mg} / \mathrm{kgBB} .{ }^{21}$ Penyerapan farmakokinetik lidokain dengan teknik tumesen terjadi puncak tingkat plasma lidokain pada 12-15 jam setelah dimulainya infiltrasi. Teknik tumesen bisa juga digunakan dalam tindakan-tindakan selain liposuction termasuk eksisi dengan formula yang sama, namun dengan takaran yang berbeda. ${ }^{19,21}$

Teknik tumesen memiliki berbagai keuntungan, seperti mengurangi jumlah perdarahan, efek anastesi yang lebih lama, kesembuhan luka yang lebih cepat, melindungi oragan yang berada di bawah kulit, dan juga dapat mengurangi kemungkinan untuk infeksi. ${ }^{20,21}$

Pada kasus, karena lokasi lesi berada di telinga yang rawan perdarahan, maka digunakan teknik anastesi tumesen untuk mengurangi jumlah perdarahan dan mengurangi risiko infeksi yang dapat terjadi. Pada kasus, digunakan formula campuran $2 \mathrm{ml}$ pehacain (mengandung lidokain dan epineprin) dengan $10 \mathrm{ml}$ larutan salin ( $\mathrm{Nacl} 0,9 \%$ ) yang dicampur di dalam spuite $10 \mathrm{ml}$ sebanyak 2 buah.

Prognosis pada laporan kasus ini adalah dubius karena rekurensi keloid bergantung kepada kepatuhan pengobatan pasien oleh karenanya diperlukan follow up pasca terapi untuk melihat terjadinya rekurensi keloid. Pasien diberikan instruksi untuk menghindari terjadinya trauma pada lokasi keloid tersebut dan kontrol tiap bulan untuk injeksi triamcinolone acetonide.

\section{SIMPULAN}

Telah dilaporkan kasus keloid aurikularis dekstra pada seorang perempuan berusia 28 tahun. Diagnosis ditegakkan berdasarkan anamnesis bekas didapatkan adanya benjolan pada telinga kanan sejak balita setelah terkena air panas. Pada pemeriksaan klinis didapatkan effloresensi nodul soliter sewarna kulit, ukuran $5 \times 7 \mathrm{~cm}$, batas tegas, tepi regular, permukaan halus dan mengkilat. Pada palpasi didapatkan kosistensi keras dan terfiksir Penatalaksanaan yang diberikan kepada pasien adalah eksisi intralesi yang dilakukan dengan anastesi tumesen, diikuti dengan injeksi kortikosteroid, dan pemberian sefadroxil serta asam mefenamat. Prognosis pada pasien adalah dubius ad bonam.

\section{KONFLIK KEPENTINGAN}

Penulis menyatakan tidak terdapat konflik kepentingan terkait publikasi dari laporan kasus ini.

\section{ETIKA DALAM PENELITIAN}

Pasien telah menandatangai persetujuan inform consent terkait fotografi dari pasien yang akan dimuat dalam jurnal ilmiah kedokteran.

\section{DAFTAR PUSTAKA}

1. Burrows NP, Lovell CR. Disorders of Connective Tissue. Keloids and hypertrophic scars. In: Burns, T, Breathnach, S, Cox, N, Griffiths, C. editors. Rook's Textbook of Dermatology. $8^{\text {th }}$ edition. 2010; p. 45.54-6.

2. Ko CJ. Dermal Hypertrophies and Benign Fibroblastic/ Myofibroblastic Tumors. In: Goldsmith, L.A, Katz, S.I, Gilchrest, B.A, Paller, A.S, Leffell, D.J, Wolff, K. editors. Fitzpatrick's Dermatology in General Medicine. $8^{\text {th }}$ edition. New York: McGraw-Hill; 2012; p. 707-717.

3. James WD, Berger TG, and Elston, DM. Dermal and Subcutaneous Tumor. Fibrous Tissue Abnormalities. Andrews' Disease of the Skin Clinical Dermatology. $11^{\text {th }}$ edition. 2011; p. 593-4.

4. Morosolli ARC, et al. Surgical Treatment of Earlobe Keloid with $\mathrm{CO}_{2}$ Laser Radiation: Case Report and Clinical Standpoints. Journal of Cosmetic and Laser Therapy. 2008;10: 226-230.

5. Tziotzios C, Profyris C, and Sterling J. Cutaneous Scarring: Pathophysiology, molecular mechanisms and scar reduction therapeutics. Part II Strategies to reduce scar formation after dermatologic procedures. Journal American Academy of Dermatology. 2012;24:13-22.

6. Nicolleti G, et al. Clinical and Histologic Effects from $\mathrm{CO}_{2}$ Laser Treatment of Keloids. Lasers Med Sci. 2013;28:957-964.

7. Kraeva E, Ho D, Jagdeo J. Successful Treatment of Keloid With Fractionated Carbon Dioxide (CO2) Laser and Laser-Assisted Drug Delivery of Triamcinolone Acetonide Ointment in an African-American Man. Journal of Drugs in Dermatology. 2017;16(9): 925-927.

8. Andrews, MD. Cryosurgery for Common Skin Condition. American Family Physicians. 2004;69(10):2365-72.

9. Love, PB, and Kundu RV. Keloid: An Update on Medical and Surgical Treatments. Journal of Drugs in Dermatology. 2013;12(4):403-409.

10. Goldenberg $G$ and Luber AJ. Use of Intralesion Cryosurgery as an Innovative Therapy for Keloid Scar and a review of current treatment. 2013;22:23-6.

11. Maghrabi IA, and Kabel AM. Management of Keloid and Hypertrophic Scar: Role of Nutrition, Drugs, Cryotherapy and Phototherapy. Journal of Nutrition and Health. 2014; 2(2):28-32.

12. Gauglitz GG. Management of Keloid and Hypertrophic Scars: current and emerging options. Clinical, Cosmetic and Investigational Dermatology. 2013;6:103-114. 
13. Park TH, Seo SW. Earlobe Keloids: Classification According to Gross Morphology Determines Proper Surgical Approach. American Society for Dermatologic Surgery. 2011;23: 406-412.

14. Annabathula A, Shanmuga C, Srinivas CR. Fractional Carbon Dioxide, Long Pulse Nd:YAG and Pulse Dye Laser in The Management of Keloid. Journal of Cutaneous and Aesthetic Surgery. 2017;33:10: 76-80.

15. Scrimali L, et al. Tretament of Hypertophic Scars and Keloids With A Fractional $\mathrm{CO}_{2}$ Laser: A Personal Experience. Journal Cosmetic and Laser Therapy. 2010;12: 218-221.

16. Vujevich JJ and Goldberg LH. Cryosurgery and Electrosurgery. In: Wolff K, Goldsmith LA, Katz SI, Gillchrest BA, Paller AS, Leffell DJ, eds. Fitzpatrick's Dermatology in General Medicine. $8^{\text {th }}$ ed. New York: Mc Graw Hill Medical, 2012; p. 2968-76.

17. Pasquali P, Sebastian GJ, and Zouboulis CC. Cryosurgery. In: Robinson JK, Hanke CW, Siegel DM and Fratila A, editors. Surgery of the Skin Procedural Dermatology $2^{\text {nd }} e d$. London: Elsevier. 2010; p. 153-66.
18. Castro-Ron G, and Pasquali P. Cryosurgery. In: Robinson JK, Hanke CW, Sengelmann RD and Siegel DM. editors. Surgery of the Skin Procedural Dermatology. $1^{\text {st }}$ ed. Philadelphia: Elsevier-Mosby, 2003; p. 191-202.

19. Sharma VK, and Khandpur S. Guideline for Cryotherapy. Indian Journal Dermato Venereol Lepro. 2009;75(2): 590-95.

20. O'Tooler EA, and Mellerio JE. Complication of wound healing. In: Burns, T, Breathnach S, Cox N, Griffiths C, editors. Rook's Textbook of Dermatology. $8^{\text {th }}$ edition. 2010; p. 14-16.

21. Ethan EZ, Paul C. Cutaneous Cryosurgery. American Family Physician. 2012:12(86): 1118-24.

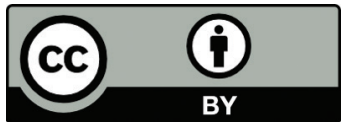

This work is licensed under a Creative Commons Attribution 